\title{
Teaching methodology used in the master's degree programme for secondary education teacher training: student assessment
}

\author{
María del Carmen Pegalajar Palomino \\ Catholic University of Murcia (UCAM), Spain | mdcpegalajar@ucam.edu
}

\section{Recommended citation:}

Pegalajar Palomino, M. C. (2015). Teaching methodology used in the master's degree programme for secondary education teacher training: student assessment. RUSC. Universities and Knowledge Society Journal, 12(3). pp. 61-71. doi http://dx.doi.org/10.7238/rusc.v12i3.2246

\begin{abstract}
This study analyses future secondary school teachers' perceptions of the teaching methodology used in a teacher training master's degree programme. A descriptive study was designed and the data were collected by adapting the "Questionnaire to evaluate university professors' teaching and assessment methodology" ( $n=252$ ). Students achieve better results under the learning-centred model, which is related to the constructivist and student-centred system, rather than a traditional teaching-centred model, which is related to the teacher whose task is to expose information to students.
\end{abstract}

\section{Keywords}

teaching methodology, evaluation, master's degree, student

\section{Metodología docente en el máster de formación del profesorado de educación secundaria: valoración del alumnado}

\section{Resumen}

El objetivo de este estudio es analizar las percepciones de los futuros docentes de educación secundaria sobre la metodología docente utilizada en el máster de formación de profesorado de educación secundaria. Para ello, se ha diseñado un estudio descriptivo y se han recogido los datos mediante la adaptación del «Cuestionario para la evaluación de la metodología docente y evaluativa de los profesores universitarios» $(n=252)$. El alumnado muestra percepciones más favorables para la escala «modelo centrado en el aprendizaje», relacionada con el modelo constructivista, centrado en el alumno, de facilitación del aprendizaje, frente al «modelo centrado en la enseñanza» de corte tradicional, centrado en el profesor, cuya tarea consiste en trasmitir la información de manera expositiva al alumnado.

\section{Palabras clave}

metodología docente, evaluación, máster, alumnado 


\section{Introduction}

The European convergence process in higher education has led to the emergence of new conceptions, approaches and a teaching practice (Margalef \& Pareja, 2008) that involves changes to teaching and assessment methodologies (Pallisera, Fullana, Planas, \& Del Valle, 2010).

In this new context, teaching should be viewed from a different angle than the one used to date (Tomusk, 2006); the teacher's role should be to enable, facilitate and guide students to learn theory and professional practices of a particular subject (Herrera, 2007) that promote their overall development (Kallioinen, 2010). The focus has been shifted towards student activity and their learning (Padilla \& Gil, 2008; Pozo \& Pérez, 2009) through the development of strategies that promote the active participation of students and techniques for independent and self-regulated learning in more flexible working environments (Kramarski \& Michalsky, 2009; Rezende, Fonseca, Nunes, Da Silva, \& Antas, 2014).

The new European process increases student satisfaction with teaching faculty and knowledge application (Otero, Ferro, \&Vila, 2012). The most highly valued aspects are personal relationships with teachers, the possibility of studying or working in other European countries, a low student-teacher ratio and the development of continuous assessment processes (López, Valles, \& Monjas, 2009; Boud \& Falchikov, 2007).

However, Carrasco (2012) highlights student criticism of compulsory class attendance and excessive workload, both individual or in groups (Korkmaz \& Yesil, 2011; Nam \& Zellner, 2011). Thus, student attitudes toward the development of blended learning strategies are positive (Jung, 2001), but the level of training of the teachers and other technical issues have been criticised (Owston, York, \& Murtha, 2013; Santamaría, Ramos, \& Sánchez, 2012). In addition, Hernández and Carrasco (2012) explain that students of master's degree programmes for secondary education teacher training are not satisfied with the set time for didactic training, the link between theory and practice in training programmes and the coordination among teachers. Thus, secondary education training must bridge the gap between the knowledge and the skills acquired in educational psychology training, review the student-teaching period of working alongside other teaching staff and include practical lines of work in the curriculum (Popa \& Bucur, 2014).

University students have internalised that methodological changes developed after the Bologna process are applied in practice in isolated cases and represent surface level changes, meaning there is a dissonance between the curriculum and what really takes place in the classroom (Hernández-Pina, 2002). Some authors (Korthagen, 2010; Recchia \& Puig, 2011) have established certain elements that jeopardise quality teacher training: disengagement and decontextualisation of the curriculum with fragmented knowledge, rote learning, theory being divorced from practice, experience and knowledge separation and the inability to carry out action research projects.

Medina, Domínguez, and Ribeiro (2011) argue that university professors develop an academic-focused teaching style that does not respond to today's knowledge society challenges, the job demands, and the changes in lifestyles and ways of life. Also, Edwards, Donderis, and Ballester (2005) reveal the limited involvement of professors and students in the process, making it necessary to implement awareness-raising actions and training policies that can change the academic culture and successfully advance towards European convergence in the Spanish university system. Gorozidis and Papaioannou (2014) even argue that political decision-makers should encourage the development of strategies that foster professor motivation to drive and implement successful educational innovations.

RUSC Vol. 12 No 3 | Universitat Oberta de Catalunya and University of New England | Barcelona, July 2015

(a) M. C. Pegalajar Palomino | @ FUOC, 2015 | Teaching methodology used in the master's degree programme for secondary education.. 
It is necessary to use active learning techniques, collaborative work, the acquisition of problem-solving skills and critical thinking development (Sáez \& Ruiz, 2012). This approach would reduce traditional on-site classroom sessions, which tend to focus on the acquisition of conceptual knowledge (Cano, 2008). Therefore, the design and creation of shared learning spaces that bridge gaps and stress relationships to foster the creation of methodologies that give rise to collaborative learning is proposed (Johnson \& Johnson, 2009).

\title{
Methodological design
}

\author{
Research objectives
}

The European convergence process and the implementation of the European Higher Education Area (EHEA) in the Spanish university system have brought significant changes to the teaching and learning process and, therefore, to the professor role. Therefore, this work analyses future secondary school teachers' perceptions of the teaching and assessment methodology used in a teacher training master's degree programme at the Catholic University of Murcia, Spain. To achieve this general aim, the following specific objectives were defined:

- To understand student perceptions of the traditional knowledge and teaching model in higher education.

- To examine student evaluations of active and constructivist knowledge and the learning model used by faculty and its implications in the classroom.

- To examine the teaching skills of postgraduate professors.

\section{Data collection instrument}

For data collection, the CEMEDEPU ("Questionnaire to evaluate university professors' teaching and assessment methodology") prepared by Gargallo, Suárez, Gargella, and Fernández (2011) was adapted. This instrument, aimed at university students, is structured into three scales with 48 items, with answer options ranging from 1 to 5 (where $1=$ strongly disagree and $5=$ strongly agree).

The instrument was developed to measure the extent to which a learning-centred model or a teaching-centred model are experienced as well as the perceived teaching skills of competent university faculty (Gargallo et al., 2011). To adapt the questionnaire to the study population, all of the items were modified and the questions were directed at the students, although the content of the questionnaire was not changed.

Thus, validity of the content was confirmed by a group of experts and through a pilot test. In the first case, several university professors who specialise in the area of teaching and school organisation from several Spanish universities were asked to make an overall assessment of the questionnaire and to indicate on a scale of 0-10 the adequacy of the initial instrument. With respect to the individual items, the experts were asked to indicate the degree to which each item was relevant to the subject under study (in content) and the degree of accuracy and adequacy (in form). In general, the evaluations by the experts showed that most of the items were valid and adequate in terms of how they were written in order to be understood by the study population. 
Once the experts had given their opinions, we proceeded to implement a pilot test on 100 students of the master's degree programme in secondary education teacher training at the University of Jaen, Spain. Thus, the KMO (Kaiser-Meyer-Olkin) sampling adequacy statistic reached a value of 0.914 and the Bartlett's sphericity test value was 6038.066 ( $p=0.000$ ). In addition, an exploratory and confirmatory factor analysis showed three factors that explained $49.03 \%$ of the variance: the first factor, comprised of 13 items based on the teaching-centred model; the second factor, comprised of 15 items based on the learning-centred model and the third scale, pertaining to teaching skills, was comprised of 20 items.

As to the reliability of the instrument, Cronbach's alpha coefficient was used and produced satisfactory results (0.956). Furthermore, the split-half method obtained a value of 0.896 for the first part and a value of 0.949 for the second, indicating that the scale is very reliable. The Spearman-Brown coefficient shows a value of 0.870, which suggests high reliability of the instrument.

\section{Sample}

The study population was comprised of 264 students of the master's degree programme to train teachers in compulsory secondary education, sixth form, vocational training and language instruction at the Catholic University of Murcia during the 2013/2014 academic year. For the selection of the sample, nonprobability sampling was used of the accidental or purposive type. Thus, subjects who chose to respond to the questionnaire were selected for the sample ( $n=252)$. To calculate the sample size, the formula for groups with fewer than 100,000 subjects was used with a confidence interval of $95 \%$ and a maximum error of the estimate of $4 \%$.

Of the sample, $59.6 \%$ were women, and $40.4 \%$ were men. The age range of the majority of the participants was between 21 and 25 years (42.9\%), followed by 26 and 30 years (33.7\%), with a slightly smaller percentage being over the age of 30 (23.4\%). With respect to their areas of specialisation, 32.7\% were specialising in Humanities, Social Sciences and Business, 27.5\% in Science and Technology, 20.3\% in Physical Education and Sports, 17.5\% in Philology and Languages and finally, 2.0\% in Fine Arts. The reason for enrolling in the master's degree programme was, for $75.7 \%$ of the participants, to become a teacher (secondary education, sixth form, vocational training, or language instruction); for $14.8 \%$, to access a doctoral education programme; and, for $9.5 \%$, to complete their studies in educational psychology.

\section{Data analysis}

To process the data, the Statistical Package for Social Sciences software (SPSS, version 21 for Windows) was used. A descriptive analysis was also carried out on each item.

Results

Students of the teacher training master's degree programme claim that professors make use of more than just exams ( $M=2.64)$ based on objective criteria $(M=3.41)$ and they claim that this is not the only or the best assessment methodology $(M=2.98)$.

They also understand that the assessment should not be limited to simple evaluation of knowledge acquired by students $(M=2.90)$. A competent university professor is someone who: adequately explains the items comprising the syllabus ( $M=3.67$ ) and has a good command of those items $(M=3.61)$; is responsible for organising the knowledge 
$(M=3.81)$ and conveying it to the students $(M=3.34)$ during face-to-face sessions $(M=3.71)$; and does not use lectures $(M=3.35)$ for the purpose of taking study notes as the fundamental methodology for instruction $(M=3.28)$.

Similarly, the participants assert that university professors understand learning as a process for gaining the knowledge made available to students on a subject area $(M=3.79)$ and they understand that higher education should not be reduced to learning and understanding the scientific content of the subject areas $(M=2.82)$.

Table 1. Descriptive analysis for the "teaching-centred model" scale

\begin{tabular}{|c|c|c|}
\hline Item & Mean & Standard deviation \\
\hline Exams are the only assessment methodology & 2.64 & 1.335 \\
\hline $\begin{array}{l}\text { University professors believe it is enough for students to learn the fundamental scientific content of the } \\
\text { subject area }\end{array}$ & 2.82 & 1.157 \\
\hline $\begin{array}{l}\text { University professors understand that assessment should be limited to the evaluation of the knowledge } \\
\text { acquired }\end{array}$ & 2.90 & 1.168 \\
\hline Exams are the best assessment methodology & 2.98 & 1.150 \\
\hline My role during face-to-face sessions is to be alert and to take study notes & 3.28 & 1.134 \\
\hline The role of the university professor is essentially to transmit knowledge to their students & 3.34 & 1.019 \\
\hline During face-to-face sessions, the lecture is the fundamental methodology used & 3.35 & 1.070 \\
\hline University professors use exams with objective criteria as an assessment methodology & 3.41 & 0.912 \\
\hline $\begin{array}{l}\text { The most important characteristic of a competent university professor is to have a good command of the } \\
\text { subject area }\end{array}$ & 3.61 & 0.960 \\
\hline A competent university professor is someone who explains the subject area well & 3.67 & 0.965 \\
\hline $\begin{array}{l}\text { University professors should use the time during face-to-face sessions to explain the contents of the subject } \\
\text { area well }\end{array}$ & 3.71 & 1.021 \\
\hline University professors understand that learning involves increasing the knowledge available to students & 3.79 & 0.951 \\
\hline $\begin{array}{l}\text { The fundamental responsibility of the university professor is to organise the knowledge that students } \\
\text { should gain }\end{array}$ & 3.81 & 0.947 \\
\hline
\end{tabular}

Second, students observe a certain level of carelessness on behalf of university professors in carrying out scientific seminars $(M=3.32)$. However, they value the use of learning contracts as an assessment methodology $(M=3.58)$, since they show real-life applications of the theory $(M=3.67)$ using case studies and/or simulations $(M=3.78)$; they use questions and systematic reflection in the classroom $(M=3.79)$ and a varied and complementary methodology $(M=3.79)$ based on the use of information and communication technologies (ICT) $(M=3.90)$. Thus, students appreciate it when university professors establish a working environment where they have an active role $(M=3.83)$, since they provide the student with the opportunity to make personal contributions to building their own knowledge $(M=3.94)$. Therefore, students perceive that university professors understand knowledge as a necessary element for interpreting reality and not just to pass a subject $(M=3.86)$.

Regarding the assessment, students claim that university professors evaluate the teaching and learning process using several methods and continuous assessment procedures to establish improvement proposals $(M=3.91)$. They also use academic mentoring with an appropriate working plan $(M=3.77)$. 
Table 2. Descriptive analysis for the "learning-centred model" scale

\begin{tabular}{|c|c|c|}
\hline Item & Mean & Standard deviation \\
\hline University professors organise seminars with students & 3.32 & 1.043 \\
\hline $\begin{array}{l}\text { University professors use learning contracts, negotiating with the student, setting tasks and work that } \\
\text { should be performed, determining the type of exams, etc. as an assessment methodology }\end{array}$ & 3.58 & 0.930 \\
\hline University professors show real-life applications of the theory & 3.67 & 0.904 \\
\hline $\begin{array}{l}\text { University professors evaluate not only to assess student results, but to get information about the learning } \\
\text { process and to introduce any necessary improvements }\end{array}$ & 3.71 & 0.875 \\
\hline $\begin{array}{l}\text { University professors use formative assessment procedures to review and to return the work with } \\
\text { instructions for improvement }\end{array}$ & 3.71 & 0.931 \\
\hline University professors use case studies and/or simulations to enhance the integration of theory and practice & 3.74 & 0.878 \\
\hline $\begin{array}{l}\text { University professors use mentoring with a working plan established beforehand and they do not simply } \\
\text { wait for students to attend }\end{array}$ & 3.77 & 1.005 \\
\hline University professors use questions and reflections systematically to help students think & 3.79 & 0.871 \\
\hline $\begin{array}{l}\text { University professors use a varied and complementary methodology according to the students' } \\
\text { characteristics }\end{array}$ & 3.79 & 0.862 \\
\hline University professors provide a working environment that fosters active student learning & 3.83 & 0.905 \\
\hline $\begin{array}{l}\text { University professors understand that the knowledge acquired by students is to interpret reality and not just } \\
\text { to pass a subject }\end{array}$ & 3.86 & 0.853 \\
\hline $\begin{array}{l}\text { The use of ICT encourages participation, interactivity and student cooperation through online sessions, } \\
\text { discussion forums, etc. }\end{array}$ & 3.90 & 0.918 \\
\hline $\begin{array}{l}\text { University professors supplement the exam as an assessment method with other training orientation } \\
\text { methods (papers, essays, etc.) }\end{array}$ & 3.91 & 0.906 \\
\hline $\begin{array}{l}\text { University professors provide students with the opportunity to make personal contributions (forums, } \\
\text { sessions, etc.) }\end{array}$ & 3.94 & 0.943 \\
\hline $\begin{array}{l}\text { A competent university professor does not present knowledge as something closed off to modification; it is } \\
\text { open to reconstruction and development by the student }\end{array}$ & 4.05 & 0.850 \\
\hline
\end{tabular}

For teaching skills, master's degree students are indifferent to being given an initial assessment by the university professors to detect prior knowledge $(M=3.20)$. However, students do value the synthesis of discussions at the beginning of the face-to-face sessions $(M=3.54)$ and at the end $(M=3.52)$, which establishes a climate of good interpersonal relations $(M=3.86)$.

In addition, students claims that the university professors consider the assessment results for planning the teaching and learning process $(M=3.56)$, since they follow up on the student learning throughout the academic year $(M=3.58)$. This process allows university professors to guide students and improve their academic performance $(M=3.78)$ according to the objectives set in the syllabus $(M=3.81)$. In addition, university professors inform the students about the methods $(M=3.88)$ and criteria for assessing the learning $(M=3.86)$ as well as the criteria developed in marking tests $(M=3.86)$.

Students think that university professors care about them personally $(M=3.69)$, and try to convey their interest in the subject $(M=3.83)$. They plan the course syllabus on a yearly basis and take time to carry out this 
$\operatorname{task}(M=3.72)$; they design clear objectives and communicate them for each of the topics covered $(M=3.76)$. In addition, university professors facilitate the course syllabus and inform the students about changes to it $(M=3.93)$, they select contents using appropriate criteria $(M=3.80)$, use a variety of resources that facilitate the presentation of the material $(M=3.77)$ and they disclose the bibliographic references for the subject $(M=3.72)$.

Table 3. Descriptive analysis for the "teaching skills" scale

\begin{tabular}{|c|c|c|}
\hline Item & Mean & Standard deviation \\
\hline University professors perform an initial assessment to identify prior student knowledge & 3.20 & 1.242 \\
\hline At the end of the face-to-face sessions, university professors summarise the discussion in the session & 3.52 & 0.974 \\
\hline $\begin{array}{l}\text { At the start of the face-to-face sessions, university professors review what has been discussed in the previous } \\
\text { session }\end{array}$ & 3.54 & 1.085 \\
\hline $\begin{array}{l}\text { University professors consider assessment results to modify their planning, methodology and teaching } \\
\text { activities in the short or medium term }\end{array}$ & 3.56 & 0.974 \\
\hline University professors evaluate at different times to review student learning & 3.58 & 1.006 \\
\hline University professors are interested in students as individuals & 3.69 & 1.024 \\
\hline Students are given bibliographic references for the subject & 3.72 & 0.909 \\
\hline Annually, university professors plan the syllabus and they take time to carry out this task & 3.72 & 0.858 \\
\hline University professors clearly communicate objectives to the students on each of the topics covered & 3.76 & 0.926 \\
\hline $\begin{array}{l}\text { University professors use a variety of resources (audiovisual, transparencies, video, whiteboard, documents, } \\
\text { etc.) to facilitate the presentation of content }\end{array}$ & 3.77 & 0.918 \\
\hline University professors guide students to improve their results & 3.78 & 0.984 \\
\hline $\begin{array}{l}\text { University professors select contents using appropriate criteria (objectives, relevance, usefulness, student } \\
\text { interest, etc.) }\end{array}$ & 3.80 & 0.848 \\
\hline University professors assess learning processes according to the objectives set in the planning & 3.81 & 0.850 \\
\hline University professors try to convey their interest in the subject to students & 3.83 & 0.877 \\
\hline Students know the criteria for marking exams used by university professors & 3.86 & 0.983 \\
\hline University professors ensure that there is a good interpersonal climate during the face-to-face sessions & 3.86 & 0.896 \\
\hline University professors inform students about the learning assessment criteria & 3.86 & 0.902 \\
\hline University professors inform students about the learning assessment methods & 3.88 & 0.913 \\
\hline University professors establish clear objectives for the subject & 3.92 & 0.851 \\
\hline University professors provide a syllabus and inform students about changes to it & 3.93 & 0.830 \\
\hline
\end{tabular}




\section{Discussion and conclusions}

This study has revealed future secondary education teachers' perceptions of the educational methodology used in the teacher training master's degree programme. Thus, it reflects on "how to teach" in order to put forward suggestions for improvement to promote quality in higher education.

In general, students achieve better results under the learning-centred model, which is related to the constructivist and student-centred system, rather than a traditional teaching-centred model. It shows positive perceptions of students towards an active and participatory methodology in the teaching and learning process (Kramarski \& Michalsky, 2009; Rezende et al., 2014), although traditional approaches are still used in higher education teaching (Sáez \& Ruiz, 2012; Medina et al., 2011).

Future teachers define a competent university professor as someone who adequately explains the content of the subject area and also has a good command over it; and as someone responsible for organising the knowledge that students should gain. In addition, students of the master's degree programme for secondary education teacher training value the use of learning contracts, case studies and/or simulations, systematic reflection in the classroom and varied and complementary methods of instruction, based on the use of ICT. These results are in line with the research by Gargallo et al. (2011), who revealed how students show a preference for university professors who understand knowledge as a construction of shared meaning, use a variety of complementary teaching methodologies, encourage self-evaluation and make use of mentoring, information technology, communication and collaborative work.

Students appreciate it when professors facilitate the subject syllabus at the beginning of the course, since this establishes clear and well-defined objectives as well as the methods and criteria for assessment. However, they complain about initial assessments at the beginning of the course for the purpose of learning about students' prior knowledge of the subject area. These results support the research of Brown, Benito, Portela, and Rodríguez (2007) and Otero et al. (2012), who reveal student satisfaction with educational management and organisation. However, it contradicts González and García (2012), who support an improvement in the management of degree programmes by fostering coordination among professors to develop an active methodology that directly involves students in the teaching and learning process.

The data collected in this work should cause university professors to reflect on the procedures that ought to be used to teach and evaluate students, especially in the context of the new higher education system as a result of the European convergence process and the implementation of European higher education. In this sense, we must develop student-centred learning, since this is an internationally useful concept and model that can be transferred to a range of settings in higher education (Bovil, Jordan, \& Watters, 2015). The design and creation of spaces that encourage the development of collaborative learning situations should also be fostered (Johnson \& Johnson, 2009) as should learning service experiences that can facilitate teacher reflection on the ethical aspects of the profession and the role those aspects play in professional work (Bell, Horn, \& Roxas, 2007; Root, 2005).

However, the small sample that has been used for this work does not guarantee the generalisation of the results to other samples. Similarly, the exclusive use of the questionnaire as a data collection instrument can lead to problems in terms of social desirability bias and the sincerity of the responses.

Further research could analyse undergraduate student perceptions and the results could be compared to those corresponding to postgraduate students, to understand their specific needs and concerns in terms of the teaching methodology.

RUSC Vol. 12 No 3 | Universitat Oberta de Catalunya and University of New England | Barcelona, July 2015

(a) M. C. Pegalajar Palomino | @ FUOC, 2015 | Teaching methodology used in the master's degree programme for secondary education... 


\section{Bibliography}

Bell, C., Horn, B., \& Roxas, K. (2007). We Know it's service, but what are they learning? Preservice Teachers' understandings of diversity. Equility \& Excellence in Education, 40, 123-133. doi: http://dx.doi.org/10.1080/10665680701218467

Boud, D., \& Falchikov, N. (2007). Rethinking Assessment in Higher Education. Learning for the long term. Oxford, UK: Routledge.

Bovill, C., Jordan, L., \& Watters, N. (2015). Transnational approaches to teaching and learning in higher education: challenges and possible guiding principles. Teaching in Higher Education, 20(1), 12-23. doi: http://dx.doi.org/10. 1080/13562517.2014.945162

Cano, M. E. (2008). La evaluación por competencias en la educación superior. Profesorado, revista de currículum y formación del profesorado, 12(3), 220-235.

Carrasco, C. (2012). ¿Cómo se está aplicando el Plan Bolonia? Una visión crítica de los alumnos de segundo curso del Grado de Psicología. In L. Del Río y Teva, I. (Comps.). IX Foro Internacional sobre la Evaluación de la Calidad de la Investigación y de la Educación Superior (pp. 532-537). Granada, Spain: Asociación Española de Psicología Conductual.

Castaño, E., Benito, A., Portela, A., \& Rodríguez, R. M. (2007). Repercusiones en los alumnos de primer curso de la implantación del Espacio Europeo. Revista Complutense de Educación, 18(1), 199-216. Retrieved from http://revistas.ucm.es/index.php/RCED/article/view/RCED0707120199A/15761

Edwards, M., Donderis, V., \& Ballester, E. (2005). La participación del profesorado y de los estudiantes: factor clave para el éxito del proceso de convergencia. Proceeding of the XIII Congreso Universitario de Innovación Educativa en las Enseñanzas Técnicas. Retrieved from http://www.eup.ulpgc.es/XIIICUIEET/Ficheros/Ponencias/22_SEP/ Sala_2/PON-D-04.pdf

Gargallo, B., Suárez, J., Gargella, P. R., \& Fernández, A. (2011). El cuestionario CEMEDEPU. Un instrumento para la evaluación de la metodología docente y evaluativa de los profesores universitarios. Estudios sobre Educación, 21, 9-40.

González, N., \& García, J. L. (2012). Metodologías participativas para la mejora del aprendizaje en Educación Superior. Un proyecto innovador con estudiantes de la Facultad de Educación. Revista lberoamericana para la Investigación y el Desarrollo Educativo, 3(5), 80-93.

Gorozidis, G., \& Papaioannou, A. G. (2014). Teachers' motivation to participate in training and to implement innovations. Teaching and Teacher Education, 39, 1-11. doi: http://dx.doi.org/10.1016/j.tate.2013.12.001

Hernández, M. J., \& Carrasco, V. (2012). Percepciones de los estudiantes del Máster en Formación del Profesorado de Educación Secundaria: fortalezas y debilidades del nuevo modelo formativo. Enseñanza \& Teaching, 30(2), $127-152$.

Hernández-Pina, F. (2002). Consistencia entre motivos y estrategias de aprendizaje en estudiantes universitarios. Revista de Investigación Educativa, 20, 487-510.

Herrera, L. (2007). Experiencia Piloto de Implantación del Sistema de Transferencia de Créditos Europeos (ECTS) en la Titulación de Maestro. Valoración del profesorado y el alumnado participante. In R. Roig (Dir.), Investigar el cambio curricular en el Espacio Europeo de Educación Superior (pp. 159-178). Alicante, Spain: Editorial Marfil.

Johnson, D. W., \& Johnson, R. T. (2009). An educational psychology success story: interdependence theory and cooperative learning. Educational Researcher, 38(5), 365-379. doi: http://dx.doi.org/10.3102/0013189X09339057 
Jung, I. (2001). Building a theoretical framework of web-based instruction in the context of distance education. British Journal of Educational Technology, 32(5), 525-534. doi: http://dx.doi.org/10.1111/1467-8535.00222

Kallioinen, O. (2010). Defining and comparing generic competencies in Higher Education. European Educational Research Journal, 9(1), 56-68. doi: http://dx.doi.org/10.2304/eerj.2010.9.1.56

Korkmaz, Ö., \& Yesil, R. (2011). Evaluation of achievement, attitudes towards technology using and opinions about group work among students working in gender based groups. Gazi University Journal of Gazi Education Faculty, 31(1), 201-229.

Korthagen, F. A. (2010). La práctica, la teoría y la persona en la formación del profesorado. Revista Interuniversitaria de Formación del Profesorado, 68(24,2), 83-102.

Kramarski, B., \& Michalsky, T. (2009). Investigating Preservice Teachers' Professional Growth in Self-Regulated Learning Environments. Journal of Educational Psychology, 101(1), 161-175. doi: http://dx.doi.org/10.1037/a0013101

López, V., Valles, C., \& Monjas, R. (Coords.) (2009). La evaluación formativa en el proceso de Convergencia hacía el EEES - Shared Assessment in the European Higher Education Area Convergence Process. Segovia, Spain: Escuela Universitaria de Magisterio de Segovia - Centro Buendía.

Margalef, L., \& Pareja, N. (2008). Un camino sin retorno: estrategias metodológicas de aprendizaje activo. Revista Interuniversitaria de Formación del Profesorado, 66(22,3), 47-62.

Medina, A., Domínguez, M. C., \& Ribeiro, F. (2011). Formación del profesorado universitario en las competencias docentes. Revista de Historia de la Educación Latinoamericana, 13(17), 119-138.

Nam, C.W., \& Zellner, R. D. (2011). The relative effects of positive interdependence and group processing on student achievement and attitude in online cooperative learning. Computers \& Education, 56, 680-688. doi: http://dx.doi. org/10.1016/j.compedu.2010.10.010

Otero, M. C., Ferro, C., \& Vila, M. (2012). Satisfacción del alumnado ante la implantación del modelo del EEES. Análisis comparativo. Hekademos: revista educativa digital, 12, 35-42.

Owston, R., York, D., \& Murtha, S. (2013). Student perceptions and achievement in a university blended learning strategic initiative. The Internet and Higher Education, 18, 38-46. doi: http://dx.doi.org/10.1016/j. iheduc.2012.12.003

Padilla, M. T., \& Gil, J. (2008). La evaluación orientada al aprendizaje en la Educación Superior: condiciones y estrategias para su aplicación en la docencia universitaria. Revista Española de Pedagogía, 241, 467-486.

Pallisera, M., Fullana, J., Planas, J., \& Del Valle, A. (2010). La adaptación al espacio europeo de educación superior en España. Los cambios/retos que implica la enseñanza basada en competencias y orientaciones para responder a ellos. Revista Iberoamericana de Educación, 54(2), 1-13.

Popa, O-R., \& Bucur, N-F. (2014). Strengths and weaknesses of the Romanian pre-service training system in prospective secondary-school teachers'view. Procedia. Social and Behavioral Sciences, 128, 256-261.

Pozo, J. I., \& Pérez, M. P. (2009). Psicología del aprendizaje universitario: la formación en competencias. Madrid, Spain: Morata.

Recchia, S., \& Puig, V. (2011). Challenges and inspirations: Student teachers' experiences in early childhood special education classrooms. Teacher Education and Special Education, 34(2), 133-151. doi: http://dx.doi. org/10.1177/0888406410387444

Rezende, F. M., Fonseca, L. J., Nunes, V., Da Silva, G., \& Antas, L. (2014). A student-centered approach for developing active learning: the construction of physical models as a teaching tool in medical physiology. BMC Medical Education, 14, 189. doi: http://dx.doi.org/10.1186/1472-6920-14-189 
Root, S. (2005). The National Service-Learning in Teacher Education Partnership: A Research Retrospective. In S. Root, J. Callahan y S. Billig (Eds.). Improving Service-Learning Practice: Research on Models to Enhance Impact. Greenwich, CT: Information Age.

Sáez, J. M., \& Ruiz, J. M. (2012). Metodología didáctica y tecnología educativa en el desarrollo de las competencias cognitivas: aplicación en contextos universitarios. Profesorado, revista de currículum y formación del profesorado, 16(3), 373-391.

Santamaría, J. S., Ramos, F. J., \& Sánchez, P. (2012). The student's perspective: teaching usages of Moodle at University. Proceedings of the ICERI 2012, Fifth International Conference of Education, Research and Innovation. Retrieved from https://ruidera.uclm.es/xmlui/bitstream/handle/10578/2897/fi_1354361781-1898.pdf?sequence=1

Tomusk, V. (2006). Creating the European Area of Higuer Education: Voices from the periphery. Dordrecht, Netherlands:

Springer. doi: http://dx.doi.org/10.1007/978-1-4020-4616-2

\section{About the authors}

María del Carmen Pegalajar Palomino

mdcpegalajar@ucam.edu

Professor, Education Department, Catholic University of Murcia (UCAM), Spain

Dr Pegalajar Palomino earned her PhD in Educational Psychology from the University of Jaen, Spain, and also holds an undergraduate degree in the field, a diploma in Elementary Education and a master's degree in Special Education. Her research focuses on inclusive education and teacher training at different educational levels.

Universidad Católica de Murcia (UCAM)

Campus Los Jerónimos, s/n

30107 Guadalupe

Murcia

Spain

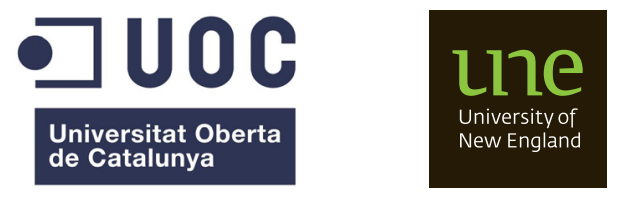

